\title{
The costs of worker displacement in urban labor markets of China
}

\author{
Yuhao $\mathrm{Ge}^{1}$ and Hartmut Lehmann ${ }^{2,3^{*}}$
}

\author{
* Correspondence: \\ hartmut.lehmann@unibo.it \\ ${ }^{2}$ University of Bologna, Bologna, \\ Italy \\ ${ }^{3}$ IZA, Bonn, Germany \\ Full list of author information is \\ available at the end of the article
}

\begin{abstract}
This paper analyzes the costs of job loss in China, using unique new data from the Rural-to-Urban Migration in China (RUMIC) data set for the year 2009. We investigate conventional labor market outcomes upon displacement like the length of unemployment spells, hours worked and monthly earnings. We also analyze whether displaced workers are more likely to be in informal employment relationships or self-employed or less happy than their non-displaced counterparts. We also look at health and psychic costs as additional outcomes. Displaced migrant workers do not encounter losses in terms of longer unemployment spells or wage penalties, while urban displaced workers incur very large costs in terms of these two outcomes. These results point to segmented urban labor markets in China. All displaced workers have an increased likelihood of being informal, while only migrants among the displaced experience a lowered incidence of self-employment. Also, health costs and psychic costs can be linked to displacement although these costs are not prevalent in a uniform fashion. Stratification of the data by gender, level of development and ownership seems important as it shows substantial heterogeneity of the costs of job loss across these dimensions.
\end{abstract}

JEL classification: J64, J65, P50

Keywords: Costs of job loss, Worker displacement, Propensity score matching, China

\section{Introduction}

In most OECD countries the costs of job loss are large for displaced workers, but these costs differ in their nature across countries. For example, in the U.S. labor market these costs are long-term even for displaced workers who find re-employment, with relative wage losses estimated to lie between 7 and 35 percent even several years after finding a new job (see Couch and Placzek 2010). In contrast, most studies on displacement in Continental Europe do not find large relative wage losses for displaced workers who have found re-employment; instead the main costs of job loss consist in foregone earnings due to periods of non-employment (see, e.g., Kuhn 2002 and Hijzen et al. 2010).

Due to a lack of appropriate data, the consequences of job loss in transition and emerging economies have received scant attention in the literature in spite of large restructuring and labor reallocation since the beginning of economic reform (Djankov and Murell 2002). Rigorous studies on worker displacement in transition economies are few: Lehmann, Philips and Wadsworth (2005), Lehmann, Pignatti and Wadsworth

\section{Springer}


(2006) and Lehmann, Muravyev, Razzolini and Zaiceva (2013) discuss the incidence and the costs of worker displacement in Estonia, Ukraine and Russia. In these studies, the authors find no relative wage losses of re-employed displaced workers, but establish large foregone earnings due to long unemployment spells for a substantial fraction of displaced workers. In contrast, the study by Orazem, Vodopivec and Wu (2005) on Slovenia finds lasting relative wage losses of re-employed displaced workers.

The small existing literature on worker displacement in China focuses on the incidence and the costs of the large retrenchment that occurred in the latter half of the 1990s. This retrenchment was connected to the restructuring of State-Owned Enterprises (SOEs), which prior to restructuring exhibited substantial labor hoarding, a phenomenon prevalent in command economies (Kornai 1992). To improve the financial position and labor productivity of SOEs, the Chinese government insisted on large labor shedding amounting to about 25 percent of the workforce in these firms (Appleton et al. 2006a). The available evidence points to very large costs for displaced workers especially in terms of foregone earnings since many of these workers had extremely long nonemployment spells. In addition, those workers who found reemployment also experienced large wage penalties ${ }^{1}$.

The analysis of worker displacement in this paper is more general for several reasons. First, it covers involuntary separations not only from SOEs but also from private firms and considers both urban workers with urban "hukou" and rural-urban migrants as populations at risk. Second, we look at the period 2003 to 2009, which is not dominated by massive government-sponsored layoffs but entails job and worker reallocation predominantly driven by market forces. Third, the 2009 wave of the Rural to Urban Migration in China (RUMIC) data set that we use covers 15 urban labor markets, embedded in regions, which vary substantially regarding their level of development, and thus allow a broader regional coverage than previous studies ${ }^{2}$. The employed data also permit a precise definition of the control group, which enables us to evaluate the costs of displacement in a more rigorous fashion.

We look at traditional labor market outcomes in connection with displacement like the length of the unemployment spell, earnings upon reemployment as well as hours worked. We also analyze whether informal or self-employment is disproportionally associated with involuntary job separations as shown by Lehmann, Razzolini and Zaiceva (2012) for the Russian labor market. We investigate whether displacement has an impact on happiness and how it affects physical and mental health. With the latter outcomes, we thus also contribute to a strand of the literature that has started to look at non-conventional outcomes that are related to workers' welfare as well as the welfare of their families. For example, Sullivan and von Wachter (2009) analyze life expectancy as an outcome and establish that displacement at age 40 will shorten the life expectancy of an average worker in the United States by 1 to 1.5 years. Lindo (2011) investigates parental job loss and infant health in the United States. His analysis reveals that husbands' job losses have significant negative effects on infant health. Liu and Zhao (2011) study a similar issue in China, looking at the effects of the mass layoff of parents in the mid-1990s on their children's health. They find that paternal job loss affects children's health negatively while maternal job loss does not show any significant effect ${ }^{3}$.

The reform of labor relations that essentially abolished guaranteed life-long employment picked up speed in the 1990s (Dong and $\mathrm{Xu}$ 2009). It led to the emergence of 
three distinct types of workers in the urban labor markets of China: workers employed in SOEs and private firms who have never been laid off, laid-off workers who are urban residents, and rural-urban migrants (Appleton et al. 2006b). Analyzing labor market developments in the wake of the reforms, Knight and Yueh (2004) try to establish the existence of a dual urban labor market in China by presenting evidence on mobility rates of migrants and urban residents. The mobility rates of migrants far exceed those of urban residents, which can be taken as evidence of a dual labor market.

Our paper, using a different perspective, also asks the question whether the evidence points to an integrated urban labor market or to a dual labor market with a competitive segment for migrants and a primary segment where urban workers, who have not been laid off, can extract some rent and some of the laid-off urban workers are rationed out of this segment. Nearly two decades into labor market adjustment we try to answer this politically relevant question by comparing the costs of displacement of migrants and urban workers in terms of the length of unemployment spells and of monthly earnings upon reemployment.

The remainder of the paper has the following structure. The next section discusses the data and gives a descriptive analysis of worker displacement in China. In section 3 we briefly sketch the empirical models used, followed by the presentation of the main results in section 4. Finally, robustness checks are discussed in the penultimate section, while in section 6 we draw some conclusions.

\section{Data and descriptive analysis}

\subsection{Data}

This paper uses the Rural to Urban Migration in China (RUMIC) dataset, which is administered by the Australian National University and Beijing Normal University of China. The RUMIC dataset has as its main focus rural-to-urban migrants. However, for comparison purposes there is also a sample of urban residents who possess urban "hukou", i.e. who have the right to reside in urban centers. The data set is conceived as a panel and thus far the two waves of 2008 and 2009 have been made available to researchers. However, only in the 2009 wave do we have precise information on the reason for job separation; so we only use this cross section of the data. We concentrate on individuals of the working age population, that is we restrict the age span to 15-65 years, resulting in 8436 and 4527 respondents in the urban sample and in the migrant sample respectively.

The data set has a retrospective part which enables us to identify a separation at any point in time between 2003 and $2009^{4}$. Vital for our analysis is, of course, information on the reason for separating from a job. The possible answers are reproduced in Table 1. They are taken from standard answers in labor force surveys administered in OECD countries but adjusted to the specifics of the Chinese labor market. As respondents are told to only give one answer it is relatively straightforward to classify job separations into quits and displacements ${ }^{5}$. Answers 1 through 5 in Table $1^{6}$ are in most cases related to involuntary job loss, although answer 5 might involve individual dismissals connected to improper behavior requiring disciplinary action. In our main analysis we classify answers 1 through 5 as involuntary job loss; we also perform robustness checks where we tighten the definition of displacement by dropping respondents giving 
Table 1 Reasons for leaving job, classification as quit or displacement, and their distribution: migrant and urban samples 2009

\begin{tabular}{llll}
\hline Reasons & Migrant & Urban & Classification \\
\hline 1 Factory bankruptcy or closure & 128 & 914 & Displacement \\
2 Moving of enterprise/organization & 29 & 85 & Displacement \\
3 Factory acquisition, restructuring and privatization & 19 & 294 & Displacement \\
4 Laid off collectively & 27 & 314 & Displacement \\
5 Dismissal initiated by employer & 48 & 66 & Displacement \\
6 Expiring of employment contract & 50 & 237 & Quit \\
7 Expiring of probation time & 15 & 17 & Quit \\
8 Own illness or injury & 34 & 79 & Quit \\
9 Studies & 21 & 27 & Quit \\
10 Retirement & 7 & 1727 & Quit \\
11 Early retirement & 6 & 406 & Quit \\
12 Marriage & 44 & 55 & Quit \\
13 Parental leave & 56 & 179 & Quit \\
14 Need to take care of other members of family & 57 & 85 & Quit \\
15 Change of residence & 13 & 70 & Quit \\
16 Wanted/was proposed job with higher salary or better working & 1167 & 680 & Quit \\
conditions & & & \\
17 Wanted/was proposed more interesting work & 222 & 133 & Quit \\
18 Wanted to start own business & 286 & 165 & Quit \\
19 Closure of own business & 34 & 69 & Quit \\
20 Other (Specify) & 429 & 266 & Quit \\
\hline
\end{tabular}

Note Authors' calculations based on 2009 wave of RUMIC data set.

answer 5. We find no substantial differences to our main analysis with the migrant sample, although, as we can infer from Table 1, those giving answer 5 are roughly 19 percent of migrant displaced workers. On the other hand, among the urban displaced only about 4 percent experience individual dismissals initiated by the employer.

The RUMIC dataset provides detailed information on demographic characteristics, happiness, health conditions, labor force status, industry affiliation and occupation, salary, formal, informal and self-employment. We will analyze the losses of displaced workers taking quitters and still-employed workers as the control group. In the questionnaire of urban sample, we use the question "So far, have you ever changed a job, resigned, retired or become unemployed". If the answer to this question is "No", then this person is identified as a still-employed worker (a stayer). If the answer to this question is "Yes", then this person is identified as a displaced worker or a quitter depending on the reason given why she or he left the last job. In the questionnaire for the migrant sample, the corresponding question asks "Is your current job the first job after migration". If the answer to this question is "Yes", then this person is identified as a stayer. A negative answer to this question identifies this person as a displaced worker or a quitter depending on the reason given for the separation from her or his last job. We are able to establish the unemployment spell of each workers who separates since we know (up to a month) the end of the previous job and the beginning of the new job ${ }^{7}$. For those who separate from a job we are thus able to calculate the months of the most recent unemployment spell. 
The empirical literature on displacement points to a strong correlation between industry affiliation and occupation on the one hand and the incidence and costs of job loss on the other hand. There are two problems with the migrant sample of the RUMIC dataset regarding industry affiliation and occupation. First, questions on working industry and occupation in the migrant sample are open questions and we have to encode them. There are more than 500 items in the variable of industry affiliation and more than 900 items in the variable of occupation. We integrate them into 9 broad industry and 5 broad occupational categories, respectively. These categories do not coincide completely with the industry and occupation codes that are given to us in the urban sample. Second, respondents in the migrant sample are reluctant to give information on, or do not know, their industry affiliation and occupation. So, once we control for these variables, the number of observations used in the analysis of the migrant sample falls substantially. We, therefore, provide both the results with only demographic and ownership controls and with industrial and occupational controls added. The latter augmented empirical models also include controls for local labor market conditions, which are crucial determinants of labor market outcomes (Heckman et al. 1999). We use city dummies to proxy local labor markets.

The number of quits in the urban sample depends crucially on how we treat retirements. Inspection of Table 1 leads us to conclude that roughly half of all quits among urban workers are retirements or early retirements. For our analysis, we exclude these observations from the subsample of quitters since we are only interested in those workers separating voluntarily from their jobs who remain in the labor force. It is noteworthy but, of course, expected that migrant workers have an extremely low incidence of retirement, amounting to no more than half a percent. When we exclude retirees and early retirees the urban sample is reduced from 8436 to 6382 observations, while the change of the migrant sample is a negligible 13 observations.

Given the large attrition of migrants that is observed between waves and associated with many of the migrants choosing to return to their rural place of origin (see, e.g., Kong et al. 2009), it can well be that the migrants who are interviewed in 2009 are a select group. Those migrants who have been displaced at some point in time between 2003 and 2009 and who remain in the urban labor market might be particularly productive and search effective in finding a new job, while the less productive among the displaced migrants might have returned home. We, however, do not think that the large differences in the costs of job loss that we observe when comparing these costs across the two samples can be entirely due to selection bias.

\subsection{Descriptive analysis}

Table 2 presents summary statistics of the three mutually exclusive subsets of the migrant and urban samples: displaced workers, quitters and stayers. The variables related to demographics, ownership type of the firm and outcomes are of particular interest and will be discussed in some detail. The distributions of industry affiliation and occupation are also shown.

Urban workers are about 7 years older on average than migrants; in the migrant sample displaced workers are somewhat older than their non-displaced counterparts, whilst in the urban sample the displaced are on average about 8 years older than quitters and 
Table 2 Summary statistics: sample means (and standard deviations)

\begin{tabular}{|c|c|c|c|c|c|c|}
\hline \multirow[b]{2}{*}{ Demographics } & \multicolumn{3}{|l|}{ Migrant } & \multicolumn{3}{|l|}{ Urban } \\
\hline & $\begin{array}{l}\text { Displaced } \\
\text { workers }\end{array}$ & Quitters\# & Stayers & $\begin{array}{l}\text { Displaced } \\
\text { workers }\end{array}$ & Quitters\# & Stayers \\
\hline \multirow[t]{2}{*}{ Age } & 33.466 & 31.162 & 31.758 & 46.470 & 38.345 & 38.519 \\
\hline & $(10.057)$ & $(9.051)$ & $(11.189)$ & $(7.454)$ & $(8.989)$ & $(10.855)$ \\
\hline \multirow[t]{2}{*}{ Male } & 0.656 & 0.607 & 0.523 & 0.506 & 0.464 & 0.545 \\
\hline & $(0.476)$ & $(0.489)$ & $(0.500)$ & $(0.500)$ & $(0.499)$ & $(0.498)$ \\
\hline \multirow[t]{2}{*}{ Married } & 0.670 & 0.655 & 0.592 & 0.926 & 0.852 & 0.775 \\
\hline & $(0.471)$ & $(0.475)$ & $(0.492)$ & $(0.261)$ & $(0.355)$ & $(0.418)$ \\
\hline \multirow[t]{2}{*}{ Yeas of education } & 9.061 & 9.298 & 9.409 & 10.519 & 11.941 & 12.447 \\
\hline & $(2.661)$ & $(2.478)$ & $(2.692)$ & $(2.765)$ & $(3.228)$ & $(3.443)$ \\
\hline \multicolumn{7}{|l|}{ Ownership of firm } \\
\hline \multirow[t]{2}{*}{ Working in SOE } & 0.135 & 0.105 & 0.151 & 0.796 & 0.405 & 0.662 \\
\hline & $(0.342)$ & $(0.306)$ & $(0.358)$ & $(0.403)$ & $(0.491)$ & $(0.473)$ \\
\hline \multicolumn{7}{|l|}{ Outcomes } \\
\hline \multirow[t]{2}{*}{ Spell of unemployment } & 4.207 & 5.083 & - & 17.151 & 8.307 & - \\
\hline & $(10.028)$ & $(11.513)$ & - & $(24.815)$ & (16.076) & - \\
\hline \multirow[t]{2}{*}{ Hours } & 60.793 & 63.529 & 61.461 & 45.692 & 45.986 & 42.974 \\
\hline & (18.102) & $(17.871)$ & (17.194) & $(12.457)$ & $(11.648)$ & $(10.163)$ \\
\hline \multirow[t]{2}{*}{ Salary } & 1352.183 & 1378.100 & 1382.712 & 1445.205 & 2094.696 & 2081.407 \\
\hline & $(560.291)$ & $(668.263)$ & (703.382) & $(1140.224)$ & $(2357.869)$ & (1677.906) \\
\hline \multirow[t]{2}{*}{ Informal employment } & 0.388 & 0.315 & 0.288 & 0.174 & 0.136 & 0.064 \\
\hline & $(0.488)$ & $(0.465)$ & $(0.453)$ & $(0.379)$ & $(0.343)$ & $(0.245)$ \\
\hline \multirow[t]{2}{*}{ Self-employment } & 0.112 & 0.258 & 0.236 & 0.086 & 0.112 & 0.055 \\
\hline & $(0.315)$ & $(0.438)$ & $(0.425)$ & $(0.281)$ & $(0.315)$ & $(0.228)$ \\
\hline \multirow[t]{2}{*}{ Health } & 0.966 & 0.979 & 0.984 & 0.948 & 0.967 & 0.979 \\
\hline & $(0.180)$ & $(0.144)$ & $(0.126)$ & $(0.222)$ & $(0.178)$ & $(0.143)$ \\
\hline \multirow[t]{2}{*}{ Depressed } & 0.103 & 0.051 & 0.050 & 0.050 & 0.041 & 0.026 \\
\hline & $(0.304)$ & $(0.221)$ & $(0.217)$ & $(0.218)$ & $(0.198)$ & $(0.160)$ \\
\hline \multirow[t]{2}{*}{ Happiness } & 0.837 & 0.874 & 0.910 & 0.893 & 0.934 & 0.947 \\
\hline & $(0.370)$ & $(0.332)$ & $(0.287)$ & $(0.309)$ & $(0.248)$ & $(0.225)$ \\
\hline \multirow[t]{2}{*}{ BMI } & 22.109 & 21.961 & 21.817 & 22.972 & 22.388 & 22.498 \\
\hline & $(3.079)$ & $(2.921)$ & $(2.955)$ & $(2.798)$ & $(2.874)$ & $(2.813)$ \\
\hline \multicolumn{7}{|l|}{ Industry } \\
\hline \multirow[t]{2}{*}{ Manufacturing } & 0.390 & 0.261 & 0.258 & 0.574 & 0.261 & 0.225 \\
\hline & $(0.488)$ & $(0.439)$ & $(0.438)$ & $(0.495)$ & $(0.439)$ & $(0.418)$ \\
\hline \multirow[t]{2}{*}{ Construction } & 0.131 & 0.142 & 0.124 & 0.064 & 0.075 & 0.069 \\
\hline & $(0.338)$ & $(0.349)$ & $(0.329)$ & $(0.245)$ & $(0.263)$ & $(0.253)$ \\
\hline \multirow[t]{2}{*}{ Low-level service } & 0.038 & 0.094 & 0.086 & 0.098 & 0.159 & 0.192 \\
\hline & $(0.191)$ & $(0.292)$ & $(0.280)$ & $(0.297)$ & $(0.365)$ & $(0.394)$ \\
\hline Wholesale and retail trade & 0.209 & 0.255 & 0.289 & 0.134 & 0.215 & 0.099 \\
\hline & $(0.407)$ & $(0.436)$ & $(0.453)$ & $(0.341)$ & $(0.411)$ & $(0.298)$ \\
\hline Hotel and catering services & 0.180 & 0.193 & 0.180 & 0.031 & 0.058 & 0.028 \\
\hline & $(0.385)$ & $(0.395)$ & $(0.385)$ & $(0.172)$ & $(0.233)$ & $(0.166)$ \\
\hline High-level service & 0.052 & 0.055 & 0.063 & 0.099 & 0.234 & 0.387 \\
\hline & $(0.223)$ & $(0.228)$ & $(0.243)$ & $(0.299)$ & $(0.423)$ & $(0.487)$ \\
\hline
\end{tabular}


Table 2 Summary statistics: sample means (and standard deviations) (Continued)

\begin{tabular}{|c|c|c|c|c|c|c|}
\hline \multicolumn{7}{|l|}{ Occupation } \\
\hline \multirow{2}{*}{$\begin{array}{l}\text { Principals in governments, parties, } \\
\text { enterprises and institutions }\end{array}$} & 0.070 & 0.103 & 0.147 & 0.022 & 0.014 & 0.070 \\
\hline & $(0.255)$ & $(0.303)$ & $(0.354)$ & $(0.148)$ & $(0.119)$ & $(0.255)$ \\
\hline \multirow[t]{2}{*}{ Professional technicians } & - & - & - & 0.150 & 0.199 & 0.267 \\
\hline & - & - & - & $(0.357)$ & $(0.399)$ & $(0.442$ \\
\hline \multirow[t]{2}{*}{ Clerk and relevant personnel } & 0.195 & 0.218 & 0.187 & 0.153 & 0.181 & 0.243 \\
\hline & $(0.397)$ & $(0.413)$ & $(0.390)$ & $(0.360)$ & $(0.386)$ & $(0.429$ \\
\hline \multirow[t]{2}{*}{ Commercial and service personnel } & 0.366 & 0.415 & 0.421 & 0.205 & 0.348 & 0.185 \\
\hline & $(0.482)$ & $(0.493)$ & $(0.494)$ & $(0.404)$ & $(0.476)$ & $(0.388$ \\
\hline \multirow[t]{2}{*}{ Manufacturing } & 0.369 & 0.265 & 0.245 & 0.413 & 0.180 & 0.163 \\
\hline & $(0.483)$ & $(0.442)$ & $(0.430)$ & $(0.493)$ & $(0.384)$ & $(0.370$ \\
\hline \multirow[t]{2}{*}{ Other practitioner (difficult to classify) } & - & - & - & 0.057 & 0.077 & 0.072 \\
\hline & - & - & - & $(0.231)$ & $(0.267)$ & $(0.259$ \\
\hline Observations & 358 & 3444 & 2184 & 1346 & 1598 & 3560 \\
\hline
\end{tabular}

Source: RUMIC data set, wave 2009.

\# Retirees and early retirees are excluded from the subsample of quitters. -- not applicable.

stayers. Among urban workers the shares of females and males are more or less equal, while in the migrant sample male workers are disproportionately represented, in particular in the subset of the displaced. A majority of all workers is married; however, urban workers have an incidence of marriage that is up to 20 percentage points larger than migrants. Unsurprisingly, urban workers are on average more educated than migrants, with the difference in years of education being particularly large for the stayers of the two samples. It is also noteworthy that displaced workers on average have the least education whether we look at migrants or urban residents.

There is a huge divergence between the two samples if we look at the ownership type of the firm in the last job (for displaced and quitters) and in the current job (for stayers). More than 80 percent of migrants worked or work in private firms, while a large majority of urban workers had the last job in an SOE or are still working in such a firm. As far as the urban sample is concerned, it is also striking that displaced workers originate much more from SOEs than quitters; so, for urban workers the state sector still drives displacement, hinting at an ongoing restructuring process of this sector.

Inspection of the spell length of unemployment in Table 2 produces two important results. First, migrants who separate from jobs have much shorter spells than their counterparts in possession of urban "hukou." Second, the average spell length of displaced and quitting migrants do not really differ while a displaced worker in the urban sample experiences extremely long and far longer spells than urban quitters. The average completed duration of more than one and a half years for displaced urban workers is in line with, e.g., the findings of Betcherman and Blunch (2006) who look at the impact of retrenchment in two large Chinese cities. So, our numbers suggest that the average laid off urban worker, if displaced from an SOE in the years 2003 to 2008, faces similar disadvantageous labor market prospects as the workers experiencing mass layoffs in the latter half of the 1990s, when the government-inspired retrenchment program was at its peak. 
Table 2 also reports the four outcomes hours, salary, informal employment and selfemployment in the current job for stayers and separators. These outcomes, therefore, are used to establish potential costs of displacement upon re-employment. The worked hours per week are in general much larger for migrants than for urban residents, which corresponds to the evidence from earlier surveys. Migrants who voluntarily separated from their jobs have a particularly long working week in their new jobs. The average monthly salary is very similar for the three subsets of the migrant sample, while upon re-employment the urban displaced seem to incur a large wage penalty relative to quitters and stayers. The incidence of informal employment, which we define as an employment relationship without contract $^{8}$, is much higher among migrants and reaches nearly 40 percent among displaced migrants. In contrast, urban displaced workers have with about 17 percent an incidence that is only a few percentage points higher than urban quitters. Particularly striking is the low incidence for urban stayers, which at around 7 percent is more than 20 percentage points lower than for their migrant counterparts. Finally, more than one fifth of all non-displaced migrants are self-employed, while displaced migrants like all three categories of urban workers on average have a percentage of self-employment that remains in the single digits.

The incidence of excellent, good or average self-assessed health ${ }^{9}$ is high in all subsets of the two samples and there are no discernible differences between the displaced and their non-displaced counterparts. Taking the Body Mass Index (BMI) as a measure of objective health we see that the average respondent is well within the norm even if urban workers have a slightly higher value. Also, there are no differences between the three categories within migrant and urban workers. So, at least as far as these unconditional statistics are concerned there seems to be no correlation between displacement and health status whether of a self-assessed or of an objective nature. When we turn to self-professed depression and happiness ${ }^{10}$ the picture is clearly different. Displaced workers have roughly twice the incidence of feeling depressed relative to stayers in both samples, with migrants in general feeling more depressed than urban workers. A mirror image of this is happiness, since displaced workers are on average roughly 7 and 5 percentage points less happy than stayers in the migrant sample and urban sample respectively. As we would expect urban resident workers seem in general happier than migrants.

The multinomial logit results for the migrant sample in Table 3 confirm that males and older workers have a higher probability to be displaced although these effects are quite small. They also show that being married and education have no predictive power regarding the likelihood of displacement. The marginal effects on industry affiliation demonstrate on the other hand that migrant workers have an especially high probability to be displaced from the manufacturing sector while being affiliated with public management and social organizations reduces the likelihood of being displaced the most. The marginal effects on the city dummies show no clear pattern since in most cities displacement is lower than in Guangzhou (the omitted category), no matter whether the city is located in a developed or less developed region.

Turning to the results for the urban sample in Table 4, being married and having more education lowers the probability of being displaced while older workers are more affected by layoffs. The most striking results are, however, linked to ownership of the firm and industrial affiliation. With working in a private firm and in agriculture as reference categories, working in an SOE and in manufacturing raises the likelihood of 
Table 3 Multinomial logit results for migrant sample - marginal effects

\begin{tabular}{|c|c|c|c|c|c|c|}
\hline & \multicolumn{3}{|c|}{$\begin{array}{l}\text { Only demographic and } \\
\text { ownership controls }\end{array}$} & \multicolumn{3}{|l|}{ All controls } \\
\hline & Displaced & Quitters\# & Stayers & Displaced & Quitters\# & Stayers \\
\hline \multicolumn{7}{|l|}{ Demographics } \\
\hline \multirow[t]{2}{*}{ Male } & $0.0144^{* * *}$ & $0.0783^{* * *}$ & $-0.0928^{* * *}$ & $0.0126^{* * *}$ & $0.0738^{* * *}$ & $-0.0864^{* * *}$ \\
\hline & $(0.00453)$ & $(0.00884)$ & $(0.00861)$ & $(0.00462)$ & $(0.00898)$ & $(0.00863)$ \\
\hline \multirow[t]{2}{*}{ Married } & -0.00446 & $0.0904^{* * *}$ & $-0.0860^{* * *}$ & -0.00155 & $0.0915^{* * *}$ & $-0.0899 * * *$ \\
\hline & $(0.00509)$ & $(0.0115)$ & $(0.0113)$ & $(0.00521)$ & (0.0113) & $(0.0109)$ \\
\hline \multirow[t]{2}{*}{ Age } & $0.00100^{* * *}$ & $-0.00510^{* * *}$ & $0.00410^{* * *}$ & $0.00120^{* * *}$ & $-0.00398^{* * *}$ & $0.00278^{* * *}$ \\
\hline & $(0.000246)$ & $(0.000574)$ & $(0.000569)$ & $(0.000252)$ & $(0.000568)$ & $(0.000558)$ \\
\hline \multirow[t]{2}{*}{ Years of education } & -0.000748 & $-0.00473^{* * *}$ & $0.00548^{* * *}$ & -0.000751 & $-0.00518^{* * *}$ & $0.00593^{* * *}$ \\
\hline & $(0.000811)$ & $(0.00179)$ & $(0.00177)$ & $(0.000857)$ & $(0.00182)$ & $(0.00178)$ \\
\hline \multicolumn{7}{|l|}{ Ownership-type firm last job } \\
\hline \multirow[t]{2}{*}{ SOE } & -0.00239 & $-0.0947^{* * *}$ & $0.0971^{* * *}$ & -0.00241 & $-0.0749^{* * *}$ & $0.0773^{* * *}$ \\
\hline & $(0.00564)$ & $(0.0127)$ & $(0.0129)$ & $(0.00569)$ & $(0.0129)$ & $(0.0129)$ \\
\hline \multicolumn{7}{|l|}{ Industry } \\
\hline \multirow[t]{2}{*}{ Construction } & & & & $-0.0229^{* * *}$ & $0.0352^{* *}$ & -0.0124 \\
\hline & & & & $(0.00386)$ & $(0.0144)$ & $(0.0143)$ \\
\hline \multirow[t]{2}{*}{ Low-level service } & & & & $-0.0272^{* * *}$ & -0.00363 & 0.0308 \\
\hline & & & & $(0.00515)$ & $(0.0190)$ & $(0.0189)$ \\
\hline \multirow[t]{2}{*}{ Wholesale and retail trade } & & & & $-0.0290^{* * *}$ & $-0.0450^{* * *}$ & $0.0740^{* * *}$ \\
\hline & & & & $(0.00378)$ & $(0.0160)$ & $(0.0160)$ \\
\hline \multirow[t]{2}{*}{ Hotel and catering services } & & & & 0.00114 & $0.0449^{* * *}$ & $-0.0460^{* * *}$ \\
\hline & & & & $(0.00738)$ & $(0.0159)$ & $(0.0153)$ \\
\hline \multirow[t]{2}{*}{ High-level service } & & & & $-0.0149^{* *}$ & -0.0223 & $0.0372^{*}$ \\
\hline & & & & $(0.00729)$ & $(0.0210)$ & $(0.0208)$ \\
\hline \multicolumn{7}{|l|}{ Occupation } \\
\hline \multirow[t]{2}{*}{ Clerk and relevant personnel } & & & & $0.0819^{* * *}$ & $0.0692^{* * *}$ & $-0.151^{* * *}$ \\
\hline & & & & $(0.0214)$ & $(0.0200)$ & $(0.0135)$ \\
\hline \multirow[t]{2}{*}{ Commercial and service personnel } & & & & $0.0270^{* *}$ & $0.0634^{* * *}$ & $-0.0904^{* * *}$ \\
\hline & & & & $(0.0130)$ & $(0.0157)$ & $(0.0132)$ \\
\hline \multirow{2}{*}{$\begin{array}{l}\text { Manufacturing and relevant } \\
\text { personnel }\end{array}$} & & & & $0.0723^{* * *}$ & $0.0524^{* *}$ & $-0.125^{* * *}$ \\
\hline & & & & $(0.0209)$ & $(0.0210)$ & $(0.0160)$ \\
\hline \multicolumn{7}{|l|}{ City } \\
\hline \multirow[t]{2}{*}{ Shenzhen } & & & & -0.00201 & 0.0132 & -0.0112 \\
\hline & & & & $(0.00849)$ & $(0.0221)$ & $(0.0220)$ \\
\hline \multirow[t]{2}{*}{ Dongguan } & & & & $-0.0227^{* * *}$ & 0.0162 & 0.00653 \\
\hline & & & & $(0.00702)$ & $(0.0221)$ & $(0.0221)$ \\
\hline \multirow[t]{2}{*}{ Zhengzhou } & & & & -0.00587 & -0.0116 & 0.0175 \\
\hline & & & & $(0.00889)$ & $(0.0215)$ & $(0.0215)$ \\
\hline \multirow[t]{2}{*}{ Luoyang } & & & & $0.0252^{*}$ & $-0.132^{* * *}$ & $0.107^{* * *}$ \\
\hline & & & & $(0.0143)$ & $(0.0242)$ & $(0.0250)$ \\
\hline Hefei & & & & $-0.0251^{* * *}$ & $-0.173^{* * *}$ & $0.198^{* * *}$ \\
\hline & & & & $(0.00653)$ & $(0.0200)$ & $(0.0205)$ \\
\hline
\end{tabular}


Table 3 Multinomial logit results for migrant sample - marginal effects (Continued)

\begin{tabular}{|c|c|c|c|c|c|c|}
\hline \multirow[t]{2}{*}{ Bengbu } & & & & $-0.0360^{* * *}$ & $-0.0939^{* * *}$ & $0.130^{* * *}$ \\
\hline & & & & $(0.00580)$ & $(0.0242)$ & $(0.0245)$ \\
\hline \multirow[t]{2}{*}{ Chongqing } & & & & 0.000241 & $-0.0604^{* * *}$ & $0.0601^{* * *}$ \\
\hline & & & & $(0.00842)$ & $(0.0193)$ & $(0.0196)$ \\
\hline \multirow[t]{2}{*}{ Shanghai } & & & & $-0.0280^{* * *}$ & $-0.185^{* * *}$ & $0.213^{* * *}$ \\
\hline & & & & $(0.00565)$ & $(0.0181)$ & $(0.0186)$ \\
\hline \multirow[t]{2}{*}{ Nanjing } & & & & $-0.0358^{* * *}$ & $-0.291^{* * *}$ & $0.327^{* * *}$ \\
\hline & & & & $(0.00437)$ & $(0.0157)$ & $(0.0164)$ \\
\hline \multirow[t]{2}{*}{ Wuxi } & & & & $-0.0341^{* * *}$ & $-0.382^{* * *}$ & $0.416^{* * *}$ \\
\hline & & & & $(0.00549)$ & $(0.0149)$ & $(0.0159)$ \\
\hline \multirow[t]{2}{*}{ Hangzhou } & & & & -0.00813 & $0.0474^{* *}$ & $-0.0393^{* *}$ \\
\hline & & & & $(0.00708)$ & $(0.0184)$ & $(0.0182)$ \\
\hline \multirow[t]{2}{*}{ Ningbo } & & & & 0.0140 & $0.0891^{* * *}$ & $-0.103^{* * *}$ \\
\hline & & & & $(0.0114)$ & $(0.0239)$ & $(0.0233)$ \\
\hline \multirow[t]{2}{*}{ Wuhan } & & & & -0.00610 & $-0.0663^{* * *}$ & $0.0724^{* * *}$ \\
\hline & & & & $(0.00743)$ & $(0.0186)$ & $(0.0188)$ \\
\hline \multirow[t]{2}{*}{ Chengdu } & & & & $-0.0176^{* *}$ & -0.00988 & 0.0275 \\
\hline & & & & $(0.00713)$ & $(0.0200)$ & $(0.0200)$ \\
\hline Pseudo $R^{2}$ & 0.0113 & & & 0.0730 & & \\
\hline Observations & 4388 & 4388 & 4388 & 4381 & 4381 & 4381 \\
\hline
\end{tabular}

being displaced by 22 and 19 percent respectively, while working in financial intermediation or in health lowers it by 21 percent. So, it is above all being tied to an SOE and to manufacturing that is associated with a layoff event. We also see that some occupations are an important predictor of layoffs pointing to the importance of controlling for occupation when evaluating the costs of job loss. Finally, in the urban sample relative to residing in Guangzhou workers residing elsewhere are more affected by displacement. Like in the migrant sample, a clear regional pattern cannot be made out since some of the cities with larger displacement are high growth regions (e.g., Shanghai) and some are located in less developed areas (e.g., Luoyang and Bengbu).

So, are displaced workers systematically different from non-displaced workers? The information thus far collected allows us to infer that displaced workers are more likely to be male, be less educated, to be older and to work disproportionately in manufacturing and in SOEs. The latter factor, however, only plays a role for the sample of urban workers. It is also noteworthy that factors related to the firm and to the job have more predictive power than demographic factors as the much larger marginal effects on the dummies for ownership type, industry affiliation and occupation attest. So, while we have a broader coverage of displacement than the previous literature we still find that most of displacement takes place in the manufacturing and the state sectors pointing to ongoing restructuring in this part of the Chinese economy. However, as an additional result we establish that the laying off of less productive workers is not confined to the state sector but economy-wide. 
Table 4 Multinomial logit results for urban sample - marginal effects

\begin{tabular}{|c|c|c|c|c|c|c|}
\hline & \multicolumn{3}{|c|}{$\begin{array}{l}\text { Only demographic } \\
\text { and ownership controls }\end{array}$} & \multicolumn{3}{|l|}{ All controls } \\
\hline & Displaced & Quitters\# & Stayers & Displaced & Quitters\# & Stayers \\
\hline \multicolumn{7}{|l|}{ Demographics } \\
\hline \multirow[t]{2}{*}{ Male } & $-0.0775^{* * *}$ & $-0.0314^{* * *}$ & $0.109^{* * *}$ & $-0.0723^{* * *}$ & $-0.0228^{* * *}$ & $0.0951^{* * *}$ \\
\hline & $(0.00732)$ & $(0.00788)$ & $(0.00976)$ & $(0.00704)$ & $(0.00800)$ & $(0.00942)$ \\
\hline \multirow[t]{2}{*}{ Married } & $-0.0336^{* *}$ & $0.0802^{* * *}$ & $-0.0467^{* * *}$ & $-0.0304^{* *}$ & $0.0921^{* * *}$ & $-0.0616^{* * *}$ \\
\hline & $(0.0153)$ & $(0.0156)$ & $(0.0162)$ & $(0.0144)$ & $(0.0157)$ & $(0.0152)$ \\
\hline \multirow[t]{2}{*}{ Age } & $0.0115^{* * *}$ & $-0.00538^{* * *}$ & $-0.00613^{* * *}$ & $0.0108^{* * *}$ & $-0.00534^{* * *}$ & $-0.00547^{* * *}$ \\
\hline & $(0.000546)$ & $(0.000529)$ & $(0.000636)$ & $(0.000523)$ & $(0.000529)$ & $(0.000615)$ \\
\hline \multirow[t]{2}{*}{ Years of education } & $-0.0229^{* * *}$ & -0.00108 & $0.0239^{* * *}$ & $-0.0109^{* * *}$ & 0.00202 & $0.00885^{* * *}$ \\
\hline & $(0.00153)$ & $(0.00142)$ & $(0.00171)$ & $(0.00158)$ & $(0.00152)$ & $(0.00174)$ \\
\hline \multicolumn{7}{|l|}{ Ownership-type firm last job } \\
\hline \multirow[t]{2}{*}{ Working in SOE in last job } & $0.146^{* * *}$ & $-0.146^{* * *}$ & 0.000392 & $0.137^{* * *}$ & $-0.130^{* * *}$ & -0.00650 \\
\hline & $(0.0120)$ & $(0.00448)$ & $(0.0118)$ & $(0.0113)$ & $(0.00514)$ & $(0.0110)$ \\
\hline \multicolumn{7}{|l|}{ Industry } \\
\hline \multirow[t]{2}{*}{ Construction } & & & & $-0.0996^{* * *}$ & 0.0303 & $0.0694^{* * *}$ \\
\hline & & & & $(0.0123)$ & $(0.0185)$ & $(0.0196)$ \\
\hline \multirow[t]{2}{*}{ Low-level service } & & & & $-0.153^{* * *}$ & -0.00408 & $0.157^{* * *}$ \\
\hline & & & & $(0.00743)$ & $(0.0131)$ & $(0.0139)$ \\
\hline \multirow[t]{2}{*}{ Wholesale and retail trade } & & & & $-0.0653^{* * *}$ & $0.0279^{*}$ & $0.0375^{* *}$ \\
\hline & & & & $(0.0127)$ & $(0.0160)$ & $(0.0181)$ \\
\hline \multirow[t]{2}{*}{ Hotel and catering services } & & & & $-0.115^{* * *}$ & 0.0370 & $0.0775^{* * *}$ \\
\hline & & & & $(0.0171)$ & $(0.0245)$ & $(0.0277)$ \\
\hline \multirow[t]{2}{*}{ High-level service } & & & & $-0.173^{* * *}$ & $-0.0247^{* *}$ & $0.198^{* * *}$ \\
\hline & & & & $(0.00663)$ & $(0.0116)$ & $(0.0124)$ \\
\hline \multicolumn{7}{|l|}{ Occupation } \\
\hline \multirow[t]{2}{*}{ Professional technicians } & & & & 0.0377 & $0.136^{* * *}$ & $-0.174^{* * *}$ \\
\hline & & & & $(0.0300)$ & $(0.0377)$ & $(0.0259)$ \\
\hline \multirow[t]{2}{*}{ Clerk and relevant personnel } & & & & 0.0369 & $0.114^{* * *}$ & $-0.151^{* * *}$ \\
\hline & & & & $(0.0298)$ & $(0.0372)$ & $(0.0270)$ \\
\hline \multirow{2}{*}{$\begin{array}{l}\text { Commercial and service } \\
\text { personnel }\end{array}$} & & & & $0.107^{* * *}$ & $0.163^{* * *}$ & $-0.269^{* * *}$ \\
\hline & & & & $(0.0343)$ & $(0.0391)$ & $(0.0214)$ \\
\hline \multirow{2}{*}{$\begin{array}{l}\text { Manufacturing and relevant } \\
\text { personnel }\end{array}$} & & & & $0.114^{* * *}$ & $0.124^{* * *}$ & $-0.239^{* * *}$ \\
\hline & & & & $(0.0327)$ & $(0.0379)$ & $(0.0228)$ \\
\hline \multirow{2}{*}{$\begin{array}{l}\text { Other practitioner (difficult to } \\
\text { classify) }\end{array}$} & & & & $0.0601^{*}$ & $0.152^{* * *}$ & $-0.213^{* * *}$ \\
\hline & & & & $(0.0349)$ & $(0.0416)$ & $(0.0272)$ \\
\hline \multicolumn{7}{|l|}{ City } \\
\hline \multirow[t]{2}{*}{ Shenzhen } & & & & 0.0436 & $-0.0369^{*}$ & -0.00671 \\
\hline & & & & $(0.0313)$ & $(0.0211)$ & $(0.0301)$ \\
\hline \multirow[t]{2}{*}{ Dongguan } & & & & $0.0515^{*}$ & $-0.0396^{* *}$ & -0.0119 \\
\hline & & & & $(0.0284)$ & $(0.0201)$ & $(0.0281)$ \\
\hline Zhengzhou & & & & $0.0498^{*}$ & $-0.144^{* * *}$ & $0.0947^{* * *}$ \\
\hline & & & & $(0.0260)$ & $(0.0140)$ & $(0.0264)$ \\
\hline
\end{tabular}


Table 4 Multinomial logit results for urban sample - marginal effects (Continued)

\begin{tabular}{|c|c|c|c|c|c|c|}
\hline \multirow[t]{2}{*}{ Luoyang } & & & & $0.0887^{* * *}$ & $-0.132^{* * *}$ & 0.0433 \\
\hline & & & & $(0.0332)$ & $(0.0216)$ & $(0.0346)$ \\
\hline \multirow[t]{2}{*}{ Hefei } & & & & 0.0152 & $-0.102^{* * *}$ & $0.0865^{* * *}$ \\
\hline & & & & $(0.0242)$ & $(0.0161)$ & $(0.0255)$ \\
\hline \multirow[t]{2}{*}{ Bengbu } & & & & $0.120^{* * *}$ & $-0.0976^{* * *}$ & -0.0229 \\
\hline & & & & $(0.0297)$ & $(0.0191)$ & $(0.0298)$ \\
\hline \multirow[t]{2}{*}{ Chongqing } & & & & -0.000614 & $-0.0804^{* * *}$ & $0.0810^{* * *}$ \\
\hline & & & & $(0.0226)$ & $(0.0156)$ & $(0.0236)$ \\
\hline \multirow[t]{2}{*}{ Shanghai } & & & & $0.0738^{* * *}$ & $0.113^{* * *}$ & $-0.187^{* * *}$ \\
\hline & & & & $(0.0242)$ & $(0.0235)$ & $(0.0228)$ \\
\hline \multirow[t]{2}{*}{ Nanjing } & & & & -0.00453 & $-0.110^{* * *}$ & $0.115^{* * *}$ \\
\hline & & & & $(0.0239)$ & $(0.0155)$ & $(0.0252)$ \\
\hline \multirow[t]{2}{*}{ Wuxi } & & & & $0.0554^{* *}$ & -0.0344 & -0.0210 \\
\hline & & & & $(0.0281)$ & $(0.0215)$ & $(0.0286)$ \\
\hline \multirow[t]{2}{*}{ Hangzhou } & & & & 0.0255 & $-0.0742^{* * *}$ & $0.0486^{*}$ \\
\hline & & & & $(0.0240)$ & $(0.0168)$ & $(0.0249)$ \\
\hline \multirow[t]{2}{*}{ Ningbo } & & & & 0.0405 & -0.000688 & -0.0398 \\
\hline & & & & $(0.0288)$ & $(0.0237)$ & $(0.0294)$ \\
\hline \multirow[t]{2}{*}{ Wuhan } & & & & $0.0785^{* * *}$ & $-0.108^{* * *}$ & 0.0298 \\
\hline & & & & $(0.0247)$ & $(0.0149)$ & $(0.0245)$ \\
\hline \multirow[t]{2}{*}{ Chengdu } & & & & $0.0675^{* * *}$ & $-0.0295^{*}$ & $-0.0380^{*}$ \\
\hline & & & & $(0.0228)$ & $(0.0168)$ & $(0.0221)$ \\
\hline Pseudo $R^{2}$ & 0.1089 & & & 0.1853 & & \\
\hline Observations & 5953 & 5953 & 5953 & 5943 & 5943 & 5943 \\
\hline
\end{tabular}

Notes: \# Retirees and early retirees are excluded from the subsample of quitters.

Default categories are: private or mixed firm for ownership-type of firm, manufacturing for industry, principals in governments, parties, enterprises and institutions for occupation, and Guangzhou for city.

*Significant at 10\%; ** significant at 5\%;*** significant at $1 \%$. Standard errors in parentheses.

In Table 5, we report the cumulative return rates to employment, conditional on unemployment duration, of migrant and urban displaced workers and compare these to return rates of those who quit. These rates are based on the complement of the Kaplan-Meier estimator of survivor functions (Smith 2002). The most striking result is the large difference in the return-to-employment pattern of migrants and urban residents. Nearly half of all displaced migrant workers return to employment within a

Table 5 Cumulative return rates to employment for quitters and displaced workers

\begin{tabular}{llllll}
\hline & \multicolumn{3}{l}{ Migrant } & & Urban \\
\cline { 2 - 3 } \% returning & Displaced Workers & Quitters\# & & Displaced Workers & Quitters\# \\
\hline$<1$ month & 0.458 & 0.498 & & 0.367 & 0.529 \\
$<3$ months & 0.776 & 0.743 & & 0.482 & 0.653 \\
$<6$ months & 0.881 & 0.843 & & 0.554 & 0.717 \\
$<12$ months & 0.929 & 0.906 & & 0.649 & 0.819 \\
Mean completed duration (months) & 4.207 & 5.083 & & 17.151 & 8.307 \\
Observations & 295 & 2991 & & 814 & 1106 \\
\hline
\end{tabular}

Source: authors' calculations based on 2009 wave of RUMIC data set. 
month, i.e. they experience a job-to-job move, and 90 percent are absorbed into employment within a year. It is also noteworthy that among migrants the displaced do not face more difficulties in finding reemployment than those who quit. For urban residents who separate from a job the situation is very different. Only a quarter of urban displaced workers experiences a job-to-job move and, what is even more striking, less than half are able to find reemployment within a year leading to very long average unemployment spells. Essentially, a minority immediately finds a new job while the rest lingers on in unemployment. For urban quitters the difficulties are less severe although only roughly two thirds find reemployment within a year.

Contrasting the cumulative return rates to employment of the migrant and urban samples we can make two inferences. First, for migrants the costs of job loss in terms of unemployment spells are mild, while they are extremely severe for urban residents. Second, the observed patterns lead us to moot that we are confronted with two distinct segments of the labor market in the cities under study: one segment for migrants, which seems quite competitive insofar as job separators are not rationed out of the market, and one segment for workers with urban "hukou" where many job separators seem to be blocked from reentering employment. We take this as a first piece of evidence that urban labor markets in China are dualistic and not integrated.

\section{Our research approach}

Our options of empirically modeling the costs of job loss are quite limited given that we can only use the cross section of 2009 of the RUMIC data set. We unfortunately cannot use a fixed effects regression, which is one of the workhorses in the displacement literature. Instead we start out with simple OLS regressions of the following type:

$$
y_{i}=X \beta+D I S_{i} \delta+\varepsilon_{i}
$$

where $y_{i}$ is labor market outcome for individual $\mathrm{i}$ and an element of the set \{unemployment spell, monthly earnings, hours worked, the incidence of informal employment, the incidence of self-employment, the BMI, the likelihood of being in good health, of feeling depressed, and of being happy\}. The vector $X$ contains demographic variables, the ownership, industry, occupation and city dummies shown in Table 2. DIS is a dummy set equal to 1 if worker i was displaced any time between 2003 and 2009. In our simple OLS specification, the coefficient $\delta$ thus captures the average effect of any displacement in the indicated period on the outcome variable. Finally, $\varepsilon$ is a white noise error term. In the case that there are no unobserved heterogenous factors that impact on the probability to be displaced and on the outcome variables of interest the average displacement effect is identified with the coefficient $\delta$. However, it is unlikely that controlling for the above mentioned conditioning variables will eliminate all selection problems. Nevertheless, while we treat our OLS results with caution, we can point out that the multinomial logit regressions show very strongly that observed firm and job related factors are far more important than observed personal characteristics, and thus probably also unobserved personal characteristics. In addition, one of our robustness checks consists in looking only at the subset of displaced related to firm closure. This scenario of displacement is often considered to have less selection problems than when predominantly redundancies are involved. As we will show, we get very similar results when only considering this subset of the displaced. 
We extend our analysis at any rate, hoping to get closer to a causal effect of displacement, by employing a matching estimator, using propensity score matching. When evaluating the costs of worker i's displacement we essentially ask the question that is posed in the evaluation literature: What is the outcome (e.g., monthly earnings, unemployment spell, etc.) of worker i who is treated (here: displaced) relative to the hypothetical outcome that would have prevailed if the same worker had not been treated (displaced)? Since the treated worker can never be observed in the non-treatment state the problem arises how to construct a credible counterfactual. When the treatment is randomized, under certain assumptions it is sufficient to compare the average outcome of the treated $\left(E\left(Y_{i}(1) \mid D_{i}=1\right)\right)$ and the average outcome of the control group (i.e. the non-treated) $E\left(Y_{i}(0) \mid D_{i}=0\right)$. The difference in these two average outcomes will identify the average treatment effect of the treated (ATT):

$$
A T T=E\left(Y_{i}(1) \mid D_{i}=1\right)-E\left(Y_{i}(0) \mid D_{i}=1\right)
$$

With randomized experiments, if we do not encounter "randomization and substitution biases" (Heckman and Smith 1995),

$$
E\left(Y_{i}(0) \mid D_{i}=1\right)=E\left(Y_{i}(0) \mid D_{i}=0\right)
$$

i.e. the average outcome of the non-treated is a consistent estimate of the counterfactual $E\left(Y_{i}(0) \mid D_{i}=1\right)$.

Alas, displacement is never a randomized treatment and we need to employ those techniques of the evaluation literature that are applied to observational data (see, e.g., Heckman, Lalonde and Smith 1999). Essentially these techniques try to get $E\left(Y_{i}(0) \mid D_{i}=0\right)$ as close as possible to the counterfactual $E\left(Y_{i}(0) \mid D_{i}=1\right)$. In this study, we employ the propensity score matching procedure proposed by Rosenbaum and Rubin (1983). For identification of a causal treatment effect they invoke the conditional independence assumption (CIA): conditional on workers' characteristics, the potential outcome in the nontreatment scenario is independent of the treatment status, i.e.

$$
E\left(Y_{i}(0) \mid D_{i}=1, P(X)\right)=E\left(Y_{i}(0) \mid D_{i}=0, P(X)\right)
$$

where $D_{i}$ is the treatment variable that takes the value 1 under treatment and the value 0 if the individual is in the non-treatment state, while $Y_{i}(0)$ is the outcome variable for individual $i$ in the non-treatment state. $P(X)$ is the propensity score, estimated with the probit model:

$$
P(X)=\operatorname{Pr}(D=1 \mid X)
$$

Matching takes place on the propensity score using the nearest neighbor method. As controls we take those who remain in their jobs (stayers) and those who quit (quitters) $)^{11}$. The covariates presented in Table 2 are used for our propensity score matching procedure.

At an intuitive level, propensity score matching attempts to balance the unobserved characteristics of two samples by balancing the observed characteristics. This works particularly well when the number of covariates is large and includes those variables that are potentially correlated with the outcome variable of interest. Employing the variables shown in Table 2 we try to balance the unobserved characteristics with our matching procedure and thus reduce selection biases. The difference in the average 
outcome of those displaced and the average outcome of the controls might thus get us closer to the causal effect of displacement:

$$
\Delta=E\left(Y_{i}(1) \mid D_{i}=1, P(X)\right)-E\left(Y_{i}(0) \mid D_{i}=0, P(X)\right)
$$

Analytical standard errors are calculated using the algorithm developed by Lechner (2001).

\section{Empirical findings on the costs of displacement}

\subsection{Overall displacement effects}

Table 6 presents the nine outcomes that we predominantly associate with a loss brought about by displacement for migrant and urban workers. The results related to unemployment spells confirm what we have learned about cumulative return rates to employment. For migrants there is no penalty associated with displacement as far as the duration of unemployment is concerned, while this penalty is between 6 and 8.5 months for the displaced among the urban residents. Putting more trust in the matching results with the full set of control variables we find that urban displaced workers have unemployment spells that are nearly three quarters of a year longer than their quitting counterparts. We also establish no wage penalty upon reemployment for migrants, while urban displaced workers experience a monthly earnings loss of between 31 and 23 percent. Worked hours per week in the current job are not affected by displacement for migrants, while they are slightly raised for urban resident workers.

Table 6 Losses associated with worker displacement

\begin{tabular}{|c|c|c|c|c|c|c|c|c|}
\hline & \multicolumn{4}{|l|}{ MIGRANT } & \multicolumn{4}{|l|}{ URBAN } \\
\hline & \multicolumn{2}{|c|}{$\begin{array}{l}\text { Demographic and } \\
\text { ownership controls }\end{array}$} & \multicolumn{2}{|c|}{ All controls } & \multicolumn{2}{|c|}{$\begin{array}{l}\text { Demographic and } \\
\text { ownership controls }\end{array}$} & \multicolumn{2}{|c|}{ All controls } \\
\hline & ols & pscore & ols & pscore & ols & pscore & ols & pscore \\
\hline \multirow[t]{2}{*}{ Unemployment spell } & -0.522 & -1.606 & -0.733 & 0.512 & $7.901^{* * *}$ & $6.046^{* * *}$ & $6.563^{* * *}$ & $8.470^{* * *}$ \\
\hline & $(0.766)$ & $(1.357)$ & $(0.774)$ & $(0.982)$ & $(1.039)$ & $(1.761)$ & $(1.128)$ & $(1.706)$ \\
\hline \multirow[t]{2}{*}{ Lnwage } & -0.038 & 0.000 & 0.002 & 0.021 & $-0.347^{* * *}$ & $-0.375^{* * *}$ & $-0.305^{* * *}$ & $-0.264^{* * *}$ \\
\hline & $(0.039)$ & $(0.076)$ & $(0.037)$ & $(0.059)$ & $(0.023)$ & $(0.053)$ & $(0.022)$ & $(0.039)$ \\
\hline \multirow[t]{2}{*}{ Hours } & $-2.610^{* * *}$ & -1.226 & -1.225 & -1.837 & $1.615^{* * *}$ & $3.303^{* * *}$ & $1.824^{* * *}$ & $2.074^{* * *}$ \\
\hline & $(1.103)$ & $(1.851)$ & $(1.049)$ & $(1.606)$ & $(0.407)$ & $(0.760)$ & $(0.420)$ & $(0.672)$ \\
\hline \multirow{2}{*}{$\begin{array}{l}\text { Informal } \\
\text { employment }\end{array}$} & $0.106^{* * *}$ & $0.118^{* * *}$ & $0.089^{* *}$ & $0.114^{* * *}$ & $0.087^{* * *}$ & $0.086^{* * *}$ & $0.094^{* * *}$ & $0.090^{* * *}$ \\
\hline & $(0.030)$ & $(0.047)$ & $(0.030)$ & $(0.045)$ & $(0.010)$ & $(0.020)$ & $(0.011)$ & $(0.017)$ \\
\hline \multirow[t]{2}{*}{ Self-employment } & $-0.162^{* * *}$ & $-0.143^{* * *}$ & $-0.099^{* * *}$ & $-0.119^{* * *}$ & 0.003 & $0.045^{* * *}$ & 0.006 & 0.009 \\
\hline & $(0.026)$ & $(0.037)$ & $(0.022)$ & $(0.034)$ & $(0.008)$ & $(0.018)$ & $(0.009)$ & $(0.015)$ \\
\hline \multirow[t]{2}{*}{ Health } & 0.000 & 0.000 & 0.000 & -0.008 & $-0.012^{* *}$ & $-0.022^{* *}$ & $-0.015^{*}$ & -0.013 \\
\hline & $(0.008)$ & $(0.013)$ & $(0.008)$ & $(0.011)$ & $(0.005)$ & $(0.014)$ & $(0.006)$ & $(0.011)$ \\
\hline \multirow[t]{2}{*}{ Happiness } & -0.028 & -0.054 & -0.030 & 0.015 & $-0.033^{* * *}$ & -0.014 & $-0.029^{* *}$ & -0.023 \\
\hline & $(0.023)$ & $(0.035)$ & $(0.023)$ & $(0.038)$ & $(0.010)$ & $(0.023)$ & $(0.011)$ & $(0.018)$ \\
\hline \multirow[t]{2}{*}{ Feel depressed } & $0.059^{* * *}$ & $0.073^{* * *}$ & $0.063^{* * *}$ & 0.040 & $0.014^{* *}$ & 0.010 & $0.025^{* * *}$ & 0.017 \\
\hline & $(0.016)$ & $(0.028)$ & $(0.016)$ & $(0.030)$ & $(0.007)$ & $(0.015)$ & $(0.008)$ & $(0.011)$ \\
\hline \multirow[t]{2}{*}{$\mathrm{BMI}$} & $-0.296^{*}$ & -0.493 & -0.184 & -0.089 & -0.042 & $-0.428^{*}$ & 0.003 & -0.115 \\
\hline & $(0.175)$ & $(0.322)$ & $(0.176)$ & $(0.290)$ & $(0.086)$ & $(0.207)$ & $(0.092)$ & $(0.143)$ \\
\hline
\end{tabular}

Source: authors' calculations based on 2009 wave of RUMIC data set. 
The first two results of our analysis strongly hint at segmentation of urban labor markets. We have a competitive segment for migrants where a new job can be found easily and where the labor supply curve is highly elastic, i.e. the new job offers in essence the same salary as the lost job, and a non-competitive segment where incumbents and quitters can extract rent while displaced workers are either completely rationed out of this part of the market or upon reemployment have to accept substantial wage cuts. The results, of course, also imply that urban displaced workers will not be hired into the competitive segment or are not willing to perform the tasks that migrant workers are asked to do.

Several studies on informal employment in emerging economies find that this employment state is undesirable for a majority of workers since they associate job insecurity, poor working conditions and lack of social protection with it (see, e.g., Lehmann, Razzolini and Zaiceva 2012a). Thus perceived, the higher incidence of informal employment due to displacement imposes especially large costs on migrant workers while these costs are more modest for the urban sample. It is worth recalling from Table 2 that informal employment, defined as working without a contract, is rather the exception than the rule even for migrant workers. The large decrease in the incidence of self-employment for displaced migrants can only be considered a cost of job loss if selfemployment is thought to be a desirable state. This conjecture is, however, controversial in the literature since many researchers consider self-employment in transition economies an employment state of last resort (see, e.g., Earle and Sakova 2000). The matching results for the urban sample are in line with this interpretation of selfemployment since they show a slight increase in self-employment associated with displacement.

Self-assessed health is not affected by displacement in the case of migrants while urban residents who are displaced are slightly less healthy. In contrast, the body mass index (BMI), considered an objective measure of health, is in most estimates not significantly lower for the displaced than for their non-displaced counterparts. Displacement makes urban workers less happy albeit only slightly, a result not observed for displaced migrant workers. In contrast, there is an increased incidence of feeling depressed, which is particularly large for this latter group. The results in essence demonstrate that in both samples there are some psychic costs brought on by displacement.

\subsection{Heterogeneous displacement effects}

The above cited literature on retrenchment establishes that the experience of displaced workers might differ by regional location, gender and age. To ascertain heterogeneous effects of displacement, we slice the urban sample by these dimensions and additionally partition the sample by ownership of the firm where the worker had her/his last job.

The results of this last partition (panel 1 of Table 7) show no differences as far as unemployment spells are concerned. Wage penalties upon reemployment, on the other hand, while existing for both types of displaced workers, are substantially larger for workers displaced from SOEs. Workers displaced from private firms incur some costs in terms of reduced working hours per week; in contrast, workers displaced from SOEs work between 3.5 and 5 hours more per week than their non-displaced counterparts. This latter result may be a reflection of a relatively short working week for stayers in 
Table 7 Heterogeneity of losses of displaced urban workers by: ownership type of firm, level of development, and gender

\begin{tabular}{|c|c|c|c|c|c|c|c|c|}
\hline \multirow{4}{*}{ Ownership } & \multicolumn{8}{|c|}{ Panel 1} \\
\hline & \multicolumn{4}{|c|}{ Private } & \multicolumn{4}{|c|}{ SOE } \\
\hline & \multicolumn{2}{|c|}{$\begin{array}{l}\text { Demographic and } \\
\text { ownership controls }\end{array}$} & \multicolumn{2}{|c|}{ All controls } & \multicolumn{2}{|c|}{$\begin{array}{l}\text { Demographic and } \\
\text { ownership controls }\end{array}$} & \multicolumn{2}{|c|}{ All controls } \\
\hline & ols & pscore & ols & pscore & ols & pscore & ols & pscore \\
\hline \multirow[t]{2}{*}{ Unemployment spell } & $4.758^{* * *}$ & $6.803^{* * *}$ & $4.431^{* * *}$ & $9.836^{* * *}$ & $8.063^{* * *}$ & $6.980^{* * *}$ & $7.311^{* * *}$ & $9.515^{* * *}$ \\
\hline & (1.493) & $(2.182)$ & $(1.528)$ & $(1.826)$ & $(1.543)$ & $(2.392)$ & $(1.626)$ & $(2.209)$ \\
\hline \multirow[t]{2}{*}{ Salary } & $-0.189^{* * *}$ & $-0.247^{* * *}$ & $-0.198^{* * *}$ & $-0.111^{*}$ & $-0.429^{* * *}$ & $-0.438^{* * *}$ & $-0.340^{* * *}$ & $-0.278^{* * *}$ \\
\hline & $(0.050)$ & $(0.081)$ & $(0.046)$ & $(0.076)$ & $(0.026)$ & $(0.057)$ & $(0.025)$ & $(0.048)$ \\
\hline \multirow[t]{2}{*}{ Hours } & $-3.204^{* * *}$ & -1.016 & $-2.541^{* * *}$ & -1.421 & $4.207^{* * *}$ & $4.984^{* * *}$ & $3.461^{* * *}$ & $4.010^{* * *}$ \\
\hline & $(0.974)$ & $(1.340)$ & $(0.960)$ & $(1.310)$ & $(0.418)$ & $(0.717)$ & $(0.447)$ & $(0.684)$ \\
\hline \multirow{2}{*}{$\begin{array}{l}\text { Informal } \\
\text { employment }\end{array}$} & 0.014 & $0.066^{* *}$ & 0.016 & 0.044 & $0.123^{* * *}$ & $0.122^{* * *}$ & $0.121^{* * *}$ & $0.115^{* * *}$ \\
\hline & $(0.025)$ & $(0.036)$ & $(0.024)$ & $(0.034)$ & $(0.011)$ & $(0.018)$ & $(0.011)$ & $(0.016)$ \\
\hline \multirow[t]{2}{*}{ Self-employment } & $-0.125^{* * *}$ & $-0.063^{* *}$ & $-0.103^{* * *}$ & $-0.092^{* * *}$ & $0.071^{* * *}$ & $0.080^{* * *}$ & $0.059^{* * *}$ & $0.066^{* * *}$ \\
\hline & $(0.023)$ & $(0.032)$ & $(0.022)$ & $(0.030)$ & $(0.008)$ & $(0.013)$ & $(0.009)$ & $(0.013)$ \\
\hline \multirow[t]{2}{*}{ Health } & 0.000 & 0.022 & -0.001 & 0.007 & $-0.022^{* * *}$ & $-0.025^{* *}$ & $-0.019^{* * *}$ & -0.011 \\
\hline & $(0.010)$ & $(0.020)$ & $(0.010)$ & $(0.016)$ & $(0.007)$ & $(0.014)$ & $(0.007)$ & $(0.012)$ \\
\hline \multirow[t]{2}{*}{ Happiness } & $-0.026^{* *}$ & -0.011 & -0.029 & $-0.048^{* *}$ & $-0.039^{* * *}$ & $-0.042^{* *}$ & $-0.034^{* * *}$ & -0.024 \\
\hline & $(0.019)$ & $(0.033)$ & $(0.020)$ & $(0.029)$ & $(0.012)$ & $(0.023)$ & $(0.013)$ & $(0.023)$ \\
\hline \multirow[t]{2}{*}{ Feel depressed } & $0.052^{* * *}$ & $0.054^{* * *}$ & $0.052^{* * *}$ & $0.065^{* * *}$ & $0.013^{* * *}$ & $0.021^{* *}$ & $0.014^{* * *}$ & 0.004 \\
\hline & $(0.016)$ & $(0.026)$ & $(0.017)$ & $(0.026)$ & $(0.008)$ & $(0.013)$ & $(0.009)$ & $(0.014)$ \\
\hline \multirow[t]{3}{*}{ BMl } & 0.087 & -0.270 & 0.069 & -0.198 & 0.012 & $-0.468^{* *}$ & 0.007 & 0.009 \\
\hline & $(0.176)$ & $(0.292)$ & $(0.178)$ & $(0.267)$ & $(0.103)$ & $(0.213)$ & $(0.110)$ & $(0.167)$ \\
\hline & \multicolumn{8}{|c|}{ Panel 2} \\
\hline \multirow{2}{*}{$\begin{array}{l}\text { Level of } \\
\text { development }\end{array}$} & \multicolumn{4}{|c|}{ Cities in developed regions\# } & \multicolumn{4}{|c|}{ Cities in less developed regions\#\# } \\
\hline & ols & pscore & ols & pscore & ols & pscore & ols & pscore \\
\hline \multirow[t]{2}{*}{ Unemployment spell } & $10.809^{* * *}$ & $11.998^{* * *}$ & $9.408^{* * *}$ & $6.395^{* * *}$ & $4.477^{* * *}$ & $5.547^{* * *}$ & $3.949^{* * *}$ & $6.846^{* * *}$ \\
\hline & $(1.751)$ & $(2.530)$ & $(1.959)$ & $(2.959)$ & $(1.234)$ & $(2.052)$ & $(1.310)$ & $(1.848)$ \\
\hline \multirow[t]{2}{*}{ Salary } & $-0.397^{* * *}$ & $-0.340^{* * *}$ & $-0.349^{* * *}$ & $-0.301^{* * *}$ & $-0.297^{* * *}$ & $-0.173^{* * *}$ & $-0.262^{* * *}$ & $-0.226^{* * *}$ \\
\hline & $(0.030)$ & $(0.051)$ & $(0.031)$ & $(0.051)$ & $(0.032)$ & $(0.063)$ & $(0.032)$ & $(0.055)$ \\
\hline Hours & $2.319^{* * *}$ & $1.911^{* *}$ & $2.539^{* * *}$ & $2.350^{* * *}$ & $0.858^{*}$ & $2.328^{* * *}$ & $1.162^{* * *}$ & $1.737^{* * *}$ \\
\hline & $(0.595)$ & $(1.026)$ & $(0.622)$ & $(0.972)$ & $(0.545)$ & $(0.968)$ & $(0.563)$ & $(0.816)$ \\
\hline Informal & $0.103^{* * *}$ & $0.098^{* * *}$ & $0.108^{* * *}$ & $0.118^{* * *}$ & $0.068^{* * *}$ & $0.072^{* * *}$ & $0.083^{* * *}$ & $0.100^{* * *}$ \\
\hline & $(0.013)$ & $(0.023)$ & $(0.015)$ & $(0.021)$ & $(0.015)$ & $(0.025)$ & $(0.016)$ & $(0.024)$ \\
\hline Self-employment & 0.002 & -0.007 & 0.009 & 0.013 & 0.004 & $0.043^{* *}$ & 0.006 & $0.033^{* * *}$ \\
\hline & $(0.012)$ & $(0.023)$ & $(0.013)$ & $(0.022)$ & $(0.012)$ & $(0.021)$ & $(0.013)$ & $(0.019)$ \\
\hline Health & -0.010 & -0.017 & -0.017 & $-0.020^{* *}$ & -0.015 & $-0.024^{* *}$ & $-0.014^{*}$ & -0.005 \\
\hline & $(0.008)$ & $(0.015)$ & $(0.008)$ & $(0.014)$ & $(0.008)$ & $(0.017)$ & $(0.008)$ & $(0.014)$ \\
\hline Happiness & $-0.047^{* * *}$ & $-0.081^{* * *}$ & $-0.046^{* * *}$ & -0.028 & -0.019 & -0.025 & -0.018 & -0.011 \\
\hline & $(0.014)$ & $(0.023)$ & $(0.015)$ & $(0.025)$ & $(0.015)$ & $(0.028)$ & $(0.015)$ & $(0.026)$ \\
\hline Feel depressed & 0.018 & 0.019 & $0.032^{* * *}$ & 0.009 & 0.008 & 0.002 & 0.019 & 0.007 \\
\hline & $(0.011)$ & $(0.018)$ & $(0.011)$ & $(0.019)$ & $(0.010)$ & $(0.019)$ & $(0.011)$ & $(0.017)$ \\
\hline BMI & $-0.237^{* * *}$ & $-0.327^{*}$ & -0.066 & -0.054 & $0.191^{*}$ & -0.268 & $0.173^{*}$ & -0.011 \\
\hline & $(0.115)$ & $(0.202)$ & $(0.124)$ & $(0.193)$ & $(0.128)$ & $(0.260)$ & $(0.137)$ & $(0.216)$ \\
\hline
\end{tabular}


Table 7 Heterogeneity of losses of displaced urban workers by: ownership type of firm, level of development, and gender (Continued)

\begin{tabular}{|c|c|c|c|c|c|c|c|c|}
\hline \multirow{3}{*}{ Gender } & \multicolumn{8}{|c|}{ Panel 3} \\
\hline & \multicolumn{4}{|l|}{ Female } & \multicolumn{4}{|l|}{ Male } \\
\hline & ols & pscore & ols & pscore & ols & pscore & ols & pscore \\
\hline \multirow[t]{2}{*}{ Unemployment spell } & $6.915^{* * *}$ & 3.912 & $5.362^{* * *}$ & 1.256 & $8.540^{* * *}$ & $8.890^{* * *}$ & $7.238^{* * *}$ & $10.151^{* * *}$ \\
\hline & $(1.650)$ & $(3.075)$ & $(1.820)$ & (3.384) & (1.319) & $(1.854)$ & $(1.427)$ & $(1.914)$ \\
\hline \multirow[t]{2}{*}{ Salary } & $-0.307^{* * *}$ & $-0.283^{* * *}$ & $-0.288^{* * *}$ & $-0.260^{* * *}$ & $-0.383^{* * *}$ & $-0.458^{* * *}$ & $-0.329^{* * *}$ & $-0.326^{* * *}$ \\
\hline & $(0.033)$ & $(0.082)$ & $(0.032)$ & $(0.061)$ & $(0.031)$ & $(0.064)$ & $(0.030)$ & $(0.049)$ \\
\hline \multirow[t]{2}{*}{ Hours } & 0.318 & 1.387 & 0.593 & $1.480^{*}$ & $2.660^{* * *}$ & $4.257^{* * *}$ & $2.650^{* * *}$ & $2.708^{* * *}$ \\
\hline & $(0.600)$ & $(1.156)$ & $(0.632)$ & $(0.866)$ & $(0.555)$ & $(0.954)$ & $(0.568)$ & $(0.902)$ \\
\hline \multirow{2}{*}{$\begin{array}{l}\text { Informal } \\
\text { employment }\end{array}$} & $0.087^{* * *}$ & $0.094^{* * *}$ & $0.086^{* * *}$ & $0.095^{* * *}$ & $0.086^{* * *}$ & $0.088^{* * *}$ & $0.098^{* * *}$ & $0.108^{* * *}$ \\
\hline & $(0.015)$ & $(0.029)$ & $(0.017)$ & $(0.025)$ & $(0.013)$ & $(0.026)$ & $(0.014)$ & $(0.021)$ \\
\hline \multirow[t]{2}{*}{ Self-employment } & -0.009 & 0.015 & -0.009 & 0.021 & 0.014 & $0.052^{* * *}$ & 0.016 & 0.015 \\
\hline & $(0.011)$ & $(0.025)$ & $(0.013)$ & $(0.018)$ & $(0.013)$ & $(0.027)$ & $(0.013)$ & $(0.022)$ \\
\hline \multirow[t]{2}{*}{ Health } & -0.010 & -0.017 & -0.016 & -0.023 & -0.014 & $-0.029^{* *}$ & -0.014 & 0.001 \\
\hline & $(0.008)$ & $(0.022)$ & $(0.009)$ & $(0.015)$ & $(0.008)$ & $(0.019)$ & $(0.008)$ & $(0.014)$ \\
\hline \multirow[t]{2}{*}{ Happiness } & $-0.025^{* *}$ & -0.017 & $-0.022^{*}$ & -0.034 & $-0.046^{* * *}$ & -0.005 & $-0.042^{* * *}$ & -0.021 \\
\hline & $(0.013)$ & $(0.030)$ & $(0.015)$ & $(0.021)$ & $(0.015)$ & $(0.035)$ & $(0.016)$ & $(0.027)$ \\
\hline \multirow[t]{2}{*}{ Feel depressed } & 0.002 & -0.002 & 0.018 & 0.000 & $0.028^{* *}$ & 0.028 & $0.032^{* * *}$ & 0.003 \\
\hline & $(0.010)$ & $(0.021)$ & $(0.011)$ & $(0.015)$ & $(0.011)$ & $(0.020)$ & $(0.012)$ & $(0.019)$ \\
\hline \multirow[t]{2}{*}{$\mathrm{BMl}$} & $0.171^{*}$ & -0.314 & 0.153 & -0.034 & $-0.251^{* * *}$ & $-0.553^{* * *}$ & $-0.188^{* *}$ & $-0.225^{*}$ \\
\hline & $(0.119)$ & $(0.302)$ & $(0.130)$ & $(0.215)$ & $(0.122)$ & $(0.259)$ & $(0.127)$ & $(0.195)$ \\
\hline
\end{tabular}

Notes: Female displaced, quitters and stayers 665,857 and 1619 respectively;

Male displaced, quitters and stayers 681,741 and 1940 respectively.

Private displaced, quitters and stayers 273,950 and 1029 respectively;

SOE displaced, quitters and stayers 1068,646 and 2011 respectively.

\# Guangzhou, Shenzhen, Dongguan, Shanghai, Nanjing, Wuxi, Hangzhou, Ningbo: displaced, quitters and stayers 629,

911 and 1562 respectively;

\#\# Zhengzhou, Luoyang, Hefei, Bengbu, Chongqing, Wuhan, Chengdu: displaced, quitters and stayers 717, 687 and 1998 respectively.

Source: authors' calculations based on 2009 wave of RUMIC data set.

the state sector. Relative to quitters and stayers only workers laid off from a job in the state sector have a higher incidence of informal employment. Those laid off from private firms are far less likely to be self-employed in the new job than their nondisplaced counterparts while the reverse effect can be seen for workers being laid off from SOEs. Given that SOEs predominantly lay off workers from the lower end of the skills distribution, this points to the interpretation of self-employment as a last resort. Self-assessed health is slightly worse only for those displaced from SOEs, while displaced from both types of firms feel less happy than the non-displaced. The mirror image of this is a higher likelihood of feeling depressed for all laid off urban workers.

Turning to the level of development (panel 2 of Table 7) displacement is associated with substantially longer unemployment spells only for workers residing in developed regions. One reason might be the more generous income support available to displaced workers in these regions (Giles et al. 2005). Wage penalties are slightly larger in the more developed regions, while the larger number of working hours and the higher incidence of an informal current job is essentially the same in both subsamples. Increased self-employment, on the other hand, can only be found in the less developed regions. 
Health is weakly negatively associated with layoffs in both types of regions. In contrast the negative (positive) impact of displacement on happiness (feeling depressed) is given in regions, where there is more development.

Men are more penalized than women regarding the increased spell of unemployment, whilst wage penalties and the increase in working hours do not differ markedly by gender (panel 3 of Table 7). After a layoff event, both sexes experience more informality in the current job, but only males have a slightly increased incidence of self-employment and lower self-assessed and objective health.

When we divide displaced workers by age we find that those who were 40 years of age or less at the time of job separation incur higher costs of job loss than older workers as far as an increased incidence of informal employment in the current job is concerned. For the other outcomes we do not find any systemic patterns and, therefore, do not present the numeric results for this partition of the urban displaced workers ${ }^{12}$.

In summary, after slicing the data by various dimensions our results clearly show that it is important to stratify the overall sample by level of development, gender and ownership type of firm when evaluating the economic, health and psychic costs of displacement, while age seems of lesser importance.

\section{Robustness checks}

Our first robustness check ${ }^{13}$ consists in the tightening of the displacement definition. We exclude those workers from the displacement sample who separated from their jobs because of reason 5 given in Table 1. A "dismissal initiated by employer" might entail individual layoffs connected to unsatisfactory performance or disciplinary problems. In addition, this type of dismissal might hit low productivity workers especially hard who in all likelihood perform worse upon job loss than displaced workers who separated from their jobs for one of the reasons 1 through 4 given in Table 1.

A comparison of the results using the more encompassing and the tighter definition of displacement shows only small differences regarding the length of unemployment spells for urban displaced workers. In addition, the fact that migrant displaced workers do not incur any costs in terms of prolonged unemployment is confirmed with this tighter definition of displacement. The absence of a wage penalty upon reemployment for migrant workers is also a robust result, while the wage loss found for reemployed urban displaced workers is slightly smaller than in Table 6, which can be understood as a weak confirmation of our supposition that individually dismissed workers might be on average of lower productivity. Informal employment, self-employment, self-assessed health, happiness, and feeling depressed are all associated with displacement in the same fashion as when the more encompassing definition of displacement is used. The BMI, on the other hand, is never affected by displacement.

Restricting displacement to involuntary job separations caused by firm bankruptcy or closure is often considered a way to reduce selection biases (see, e.g., Kuhn 2002). We are fortunate insofar as the majority of displacements are linked to bankruptcy or closure in the RUMIC data set, which is rather unusual in survey data. For example in Russia and Ukraine, where we have similar survey data in emerging economies, redundancies outnumber displacements due to bankruptcy and closure by a wide margin (Lehmann et al. 2012b). Since displacement events linked to bankruptcy or closure are 
considered "more exogeneous" than when redundancies are also involved, similar results with this more restrictive definition of displacement would imply that we are not just looking at correlations but a causal effect of displacement on the outcomes under study.

However, with this restrictive definition the number of observations is reduced to 128 in the case of the migrant sample, which might lead to imprecise point estimates. Reduced significance certainly should not be a problem with the urban sample since we still have around 900 observations at our disposal. In comparison with the definition that includes redundancies, one of our main results still holds: migrants do not incur costs of displacement in the form of longer unemployment spells and of wage penalties while urban residents do. Also, the magnitudes of these costs are in the same ballpark as when we include redundancies. Also, displacement has similar effects on selfemployment, self-assessed health and happiness whether we include redundancies or not. An increased likelihood of informal employment and of feeling depressed is associated with displacement but with the definition of displacement restricted to firm closure these effects are only significant in the case of urban residents. All in all, the important results related to economic losses still pertain with this restricted sample of displaced.

Our last robustness check alters the definition of controls by keeping only stayers in this group. In the early literature on displacement stayers were used to construct a counterfactual. However, more recently students of displacement have argued that stayers are too "stable" a group to be a credible counterfactual for the displaced. Instead, both stayers and quitters should be used for the construction of this credible counterfactual, since for a displaced worker the non-treatment state might be either staying at the firm or quitting the firm.

Compared to our analysis with the larger definition of controls we can establish qualitatively similar results when we use only stayers as controls. However some point estimates differ somewhat. For example, the wage penalty for urban displaced is now smaller. This is not a surprise since from Table 2 we know that quitters in the urban sample have a higher average wage than stayers. So, by not including quitters one actually understates the wage penalty. In contrast, the larger likelihood of being informally employed has an upward bias in the migrant sample, because migrant stayers have a lower incidence of informal employment than migrant quitters (see Table 2). So, on this evidence it strikes us as better to choose both stayers and quitters as controls when one wants to estimate the true level of losses associated with displacement.

Our robustness checks have shown that the results of Table 6 remain virtually always valid whatever sample of displaced or controls we use. In particular, the dualistic nature of labor markets in cities is clearly confirmed, since our basic analysis presented in Table 6 and our robustness checks all determine that displaced migrant workers are not confronted with longer job search than their non-displaced counterparts and that upon reemployment they do not face a wage penalty, while displaced urban workers incur large losses regarding these two outcomes.

\section{Conclusions}

Using unique data from the 2009 wave of the RUMIC data set, which covers 15 urban labor markets in China, we analyze the costs of worker displacement for rural-to-urban 
migrants and for workers who have urban residence rights ("hukou"). Displacement events refer to the years 2003 to 2009, which is a period marked by more natural job and worker reallocation than the late 1990s when large government-inspired restructuring programs lead to massive layoffs of workers from SOEs.

Our paper pursues two research questions. Having data that allow a precise identification of displaced workers, of quitters and of stayers, and thus of the treated (displaced) and the controls, we attempt to evaluate economic, health and psychic costs of displacement in urban labor markets of China in a rigorous fashion. A rigorous evaluation has been difficult thus far due to a lack of appropriate data. In addition, we can undertake this evaluation for workers who separate not only from SOEs but also from private firms, and for a wider regional coverage than previously possible. Our second research question wants to shed some light on the nature of urban labor markets in China. Having data on both migrants and workers with "hukou", who both are actors in urban labor markets we can compare the losses associated with displacement in terms of unemployment spells and wage penalties upon reemployment. Similar losses across the two types of workers would indicate an integrated labor market while widely diverging costs would point to labor market segmentation.

We find that displaced migrant workers do not incur any costs in terms of increased unemployment spells and of wage penalties upon reemployment. In contrast urban workers when displaced experience very large costs in terms of prolonged unemployment spells and are also confronted with wage penalties that amount to roughly 20 percent. These results are robust to the definition of displacement and to the choice of the control groups as well as when the data are stratified by ownership, gender and the level of development.

This evidence clearly points to segmentation of urban labor markets in China. There is a competitive segment for migrants where the length of job search of quitters and displaced does not differ and where displaced workers upon reemployment receive a similar wage as quitters and stayers. For urban workers there exists a labor market segment that pays higher wages than in the segment for migrants; many of the displaced workers are rationed out of this segment of the market and if they find reemployment after prolonged job search they are confronted with large wage penalties.

Once nation-wide data on displacement become available, future research thus should try to better capture the dualistic nature of urban labor markets and to identify the channels through which institutions impact on the behavior of displaced workers.

\section{Endnotes}

${ }^{1}$ See, e.g., Appleton et al. (2006a), Giles, Park and Cai (2006), Knight and Yueh (2004) and Betcherman and Blunch (2006).

${ }^{2}$ Guangzhou, Shenzhen, Dongguan, Shanghai, Nanjing, Wuxi, Hangzhou and Ningbo are the surveyed cities located in developed regions, while the cities Zhengzhou, Luoyang, Hefi, Bengbu, Chongqing, Wuhan, Chengdu are found in less developed regions.

${ }^{3}$ There are many more studies on the health costs of displacement; this growing literature is discussed in Lindo (2011).

${ }^{4}$ Since a job separation is for most workers a traumatic event, we think that recall bias is minimal or, at least, not correlated with displacement. 
${ }^{5}$ For a discussion of the pros and cons of using survey data to define displacement see the introductory chapter in Kuhn (2002).

${ }^{6}$ These answers are: (1) Factory bankruptcy or closure; (2) Moving of enterprisel organization; (3) Factory acquisition, restructuring and privatization; (4) Laid off collectively; (5) Dismissal initiated by employer.

${ }^{7}$ We can determine each spell if there is no recall error on the part of the respondents. Given the data we have we are not able to pin down the existence of recall error, but we prefer to think that in a country where life-long employment has been the rule such a dramatic event as job loss or job change can be recalled by virtually all workers with some precision.

${ }^{8}$ The literature on informality uses essentially a legalistic definition or a productivity based definition. Here we use the legalistic definition. For a discussion of definition issues regarding informality see chapter 1 of Perry et al. (2007).

${ }^{9}$ Respondents when asked about their current state of health can choose between five answers: excellent, good, average, poor and very poor. We take the first three answers as an indication of assessing oneself as being healthy.

${ }^{10}$ When asked whether they feel depressed individuals can respond not at all, a little bit, fairly seriously and very seriously. We take the last two answers to determine the incidence of feeling depressed. The way the survey solicits information, we cannot state that we are dealing with clinical depression here. The question on happiness asks: "Are you happy when you consider each aspect of life?" We take the first two answers of the possible answers very happy, fairly happy, not very happy and not happy at all as an indication of happiness.

${ }^{11}$ The recent literature selects both stayers and quitters as controls, since choosing only stayers as controls might lead to an upward bias of displacement effects. However, Davis and von Wachter (2011) find it preferable to use only stayers. As one of our robustness checks we will employ only stayers as controls.

${ }^{12}$ They are available upon request, though.

${ }^{13}$ To save space, we only discuss the results of our robustness checks without presenting them. They are, however, available upon request.

Competing interest

The IZA Journal of Labor and Development is committed to the IZA Guiding Principles of Research Integrity. The authors declare that they have observed these principles.

\section{Acknowledgments}

We are grateful to Sylvie Demurger, Corrado Giuletti, Konstantinos Tatsiramos, Zhong Zhao and two anonymous referees as well as participants of the $3^{\text {rd }}$ CIER/IZA workshop in Beijing in September 2011 for comments and suggestions. Lehmann thanks the Volkswagen Foundation for financial support within the project "The political economy of labor market reform in transition economies: A comparative perspective."

Responsible editor: Jackline Wahba

Author details

${ }^{1}$ Renmin University of China, Beijing, China. ${ }^{2}$ University of Bologna, Bologna, Italy. ${ }^{3}$ ZZA, Bonn, Germany.

References

Appleton S, Knight J, Song L, Qingjie X (2006a) Labour Retrenchment in China: Determinants and Consequences. In: Shi L, Sato H (ed) Unemployment, Inequality and Poverty in Urban China. Routledge, pp 19-42

Appleton S, Knight J, Song L, Qingjie X (2006b) Contrasting Paradigms: Segmentation and Competitiveness in the Formation of the Chinese Labour Market. In: Shi L, Sato H (ed) Unemployment, Inequality and Poverty in Urban China. Routledge, pp 212-235 
Betcherman G, Niels-Hugo B (2006) The Limited Job Prospects of Displaced Wroekrs: Evidence from Two Cities in China, Social Protection Discussion Paper No. 0613. The World Bank, Washington, D.C.

Couch KA, Placzek DW (2010) Earnings losses of displaced workers revisited. Am Econ Rev 100(1):572-589

Davis SJ, von Wachter TM (2011) Recessions and the Cost of Job Loss. National Bureau of Economic Research Working Paper No. 17638

Djankov S, Murrell P (2002) Enterprise restructuring in transition: a quantitative Survey. J Econ Lit 60:739-792

Dong X, Xu LC (2009) Labor Restructuring in China: Toward a functioning labor market. J Comp Econ 37(2):287-305 Giles J, Park A, Cai F (2006) How has Economic Restructuring Affected China's Urban Workers? The China Quarterly:61-95 Heckman JJ, LaLonde RJ, Smith JA (1999) The economics and econometrics of active labor market programs. In: Ashenfelter O, Card D (ed) Handbook of Labor Economics 3. Elsevier, Amsterdam

Heckman JJ, Smith JA (1995) Assessing the case for social experiments. J Econ Perspect 9(2):85-110

Hijzen A, Upward R, Wright PW (2010) The income losses of displaced workers. J Hum Resour 45(1):243-269

Knight J, Yueh L (2004) Job mobility of residents and migrants in urban China. J Comp Econ 32(3):637-660

Kong ST, Meng X, Zhang D (2009) Impact of economic slowdown on migrant workers. In: Garnaut R, Song L, Woo WT (ed) China's New Place in a World of Crisis: Economic, Geopolitical and Environmental Dimensions. ANU E Press, Canberra, Australia

Kornai J (1992) The Socialist System: The Political Economy of Communism. Oxford University Press. reprint 2000

Kuhn P (2002) Losing Work, Moving On: Worker Displacement: an International Perspective. W.E. Upjohn Institute for Employment Research

Lechner M (2001) Identification and estimation of causal effects of multiple treatments under the conditional independence assumption. In: Lechner M, Pfeiffer F (ed) Econometric Evaluation of Labour Market Policies. Physica, Heidelberg

Lehmann H, Razzolini T, Zaiceva A (2012a) Job Separations and Informality in the Russian Labor Market. In: Lehmann H, Tatsiramos K (ed) Informal Employment in Emerging and Transition Economies, Research in Labor Economics, 34th edition, pp 257-290

Lehmann H, Muravyev A, Pignatti N, Razzolini T, Zaiceva A (2012b) Worker Displacement in Russia and Ukraine: A Comparative Analysis using Micro Data. In: Brueck T, Lehmann H (ed) In the Grip of Transition: Economic and Social Consequences of Restructuring in Russia and Ukraine. Palgrave Macmillan, pp 7-46

Lehmann H, Muravyev A, Razzolini T, Zaiceva A (2013) The Wage and Non-wage Costs of Displacement: Evidence from Russia. J Comp Econ

Lehmann H, Philips K, Wadsworth J (2005) The Incidence and Cost of Job Loss in a Transition Economy: Displaced Workers in Estonia, 1989-1999. J Comp Econ 33:59-87

Lehmann H, Pignatti N, Wadsworth J (2006) The Incidence and Cost of Job Loss in the Ukrainian Labor Market. J Comp Econ 34:248-271

Lindo JM (2011) Parental job loss and infant health. J Health Econ 30(5):869-879

Liu H, Zhao Z (2011) Parental job loss and children's health: Ten years after the massive layoff of the SOE's workers in China. IZA Discussion Paper No. 5846

Orazem P, Vodopivec M, Wu R (2004) Worker displacement during the transition: Experience from Slovenia. Econ Transition 13:311-340

Perry G, Maloney W, Arias O, Fajnzylber P, Mason A, Saavedra-Chanduvi J (2007) Informality: Exit and Exclusion. International Bank for Reconstruction and Development/World Bank, Washington

Rosenbaum PR, Rubin DB (1983) The central role of the Propensity Score in observational studies for causal effects. Biometrika 70:41-55

Smith PJ (2002) Analysis of Survival and Failure Data. Chapman Hall, London

Sullivan D, von Wachter T (2009) Job displacement and mortality: An analysis using administrative data. Q J Econ 124(3):1265-1306

doi:10.1186/2193-9020-2-4

Cite this article as: Ge and Lehmann: The costs of worker displacement in urban labor markets of China. IZA Journal of Labor \& Development 2013 2:4.

\section{Submit your manuscript to a SpringerOpen ${ }^{\circ}$ journal and benefit from:}

- Convenient online submission

Rigorous peer review

- Immediate publication on acceptance

- Open access: articles freely available online

- High visibility within the field

- Retaining the copyright to your article

Submit your next manuscript at $\boldsymbol{\sim}$ springeropen.com 